\title{
TURIZAM NA SELJAČKIM GOSPODARSTVIMA U HRVATSKOJ
}

\author{
Aleksandar Lukić*
}

\section{Sažetak}

Ruralni turizam u Hrvatskoj i turizam na seljačkim gospodarstvima nalaze se u početnoj, pionirskoj fazi. Posljedica je to pretežite usmjerenosti hrvatskog turizma na maritimne prostore, ali i desetljećima dugog procesa zanemarivanja ruralnog prostora i obiteljskih seljačkih gospodarstava. Promjene društveno-ekonomskog sustava početkom devedesetih godina 20. stoljeća bile su poticaj razvoju ove vrste turizma u Hrvatskoj. No iako čak 3/4 ruralnih prostora Hrvatske imaju obilježja socijalno-ekonomske krize, ruralni turizam ne koristi se sustavno kao alat u revitalizaciji problemskih ruralnih prostora.

Ključne riječi: Hrvatska, integralni razvoj, ruralni turizam, turizam na obiteljskim seljačkim gospodarstvima.

\section{TOURISM ON FARMS IN CROATIA}

\begin{abstract}
Rural tourism and farm tourism in Croatia are at the pioneer stage of development. This is due mainly to state's maritime orientation in tourism, but also because of degradation of rural areas and farms during last decades. Transition to market economy at the beginning of the nineties has influenced on the rural tourism development in Croatia. Rural tourism in Croatia is not systematically used as a mean for revitalization although $3 / 4$ of rural areas in Croatia have characteristics of social and economic crisis.
\end{abstract}

Key words: Croatia, tourism on farms, integral development, rural tourism.

\footnotetext{
*Aleksandar Lukić, dipl. geogr., Prirodoslovno-matematički fakultet, Odsjek za geografiju, Maruličev trg 19, Zagreb, Hrvatska.
} 


\section{Uvod}

Ruralni prostori svijeta i Hrvatske doživljavaju transformaciju. Regionalne raznolikosti i nejednakosti tog procesa na svjetskoj razini su ogromne. No trend diverzifikacije gospodarskih djelatnosti u ruralnim prostorima sve je izraženiji i prisutniji i postaje gotovo univerzalan proces. Turizam je jedna od djelatnosti koja može imati značajan utjecaj na ekonomsku, socijalnu, funkcionalnu i fiziognomsku strukturu ruralnog prostora. Uloga turizma kao pokretača i transformatora u revitalizaciji ruralnog prostora dokazana je u brojnim europskim državama. Turizam je i djelatnost koja śe imati sve zapaženiju ulogu u stvaranju nacionalnog dohodka u 21. stoljeśu, u postindustrijskom društvu.

Veći dijelovi ruralnog prostora Hrvatske imaju obilježja populacijske i ekonomske krize. Emigracijski tipovi kretanja stanovniötva prevladavaju na više od 3/4 ruralnih prostora. Domovinski rat intenzivirao je postojeće negativne procese u dijelovima ruralnog prostora Hrvatske. Održivost većeg dijela ruralne Hrvatske ovisi o politici razvoja - demografska i ekonomska revitalizacija nije moguća vlastitim resursima rurisa.

Turizam je fenomen snažno povezan sa Hrvatskom. Tradicija turizma duža je od stoljeća, a povoljni prirodno-geografski i društveno-geografski faktori čine okvir za razvoj turizma u buduśnosti. Globalna turistička kretanja obilježena su uzlaznim trendom i sve većom zastupljenošću oblika turizma koji se razlikuju od onih obilježenih sintagmom "sun \& beach" i te će odrednice utjecati na turizam Hrvatske u narednom razdoblju. Višak slobodnog vremena uslijed skraćivanja radnog tjedna i dužeg godišnjeg odmora, višak slobodnih sredstava, moderni prometni i telekomunikacijski sustavi, viša razina naobrazbe i ekološke svijesti, samo su neke od posljedica integracije znanosti i tehnologije, tehnizacije i informatizacije Svijeta, koje utječu na jačanje turističkih kretanja. Uz sveprisutan trend pomaka od koncepta masovnog turizma $\mathrm{k}$ individualnijim i prosvjećenijim oblicima turizma, te uz evidentne napore ekonomski razvijenih država Svijeta (npr. unutar Europske unije) koje bi mogli svesti pod moto: "Ruralni prostor ima budućnost", osigurana je pozicija ruralnih područja na svjetskom turističkom tržištu 21. stoljeća. 


\section{Ruralni prostor Hrvatske}

Ruralna područja Hrvatske čine oko 90 \% kopnenog dijela Hrvatske (ili $61 \%$ naseljenog dijela Hrvatske) i u njima živi oko 47 \% ukupnog stanovništva Hrvatske. Ta su područja, još od sredine 19 st., a posebno tijekom real-socijalističkog gospodarskog sustava od sredine 1950-ih do 1990-ih godina, tranzicijom u posljednih desetak godina, te u Domovinskom ratu, bila izložena degradacijskim procesima koji su doveli do praga izumiranja rurisa, sela osnovnog elementa ruralnog prostora. Civilizacijski i historijski procesi deagrarizacije, deruralizacije, industrijalizacije i urbanizacije, prisutni u određenim fazama razvoja u svim dijelovima Svijeta, imali su izuzetno selektivan i negativan utjecaj na razvoj hrvatskog sela. Real-socijalistička planska privreda favorizirala je industrijski razvitak i Hrvatska kao tipična agrarna zemlja (1953. Hrvatska je imala 75.8 \% seoskog stanovništva i $56.4 \%$ poljoprivrednog stanovništva) podvrgnuta je "umjetnoj" deagrarizaciji koja nakon 1955. postaje izrazita. Zbog (neuspjele) kolektivizacije i nacionalizacije, lošeg položaja seljaka u sustavu koji ne trpi privatnu svojinu, te pojačane industrijalizacije i propadanja interesa za zemlju, javlja se i proces deruralizacije tj. napuštanja sela kao mjesta stanovanja. To je preseljenje bilo izuzetno selektivno - iseljavaju pretežito mladi i to muškarci. Zanimljiv je i odnos procesa deagrarizacije i deruralizacije. Deagrarizacija je u posljednjih pedesetak godina bila znatno brži proces. Veliki broj stanovnika koji živi na selu, a ne bavi se poljoprivrednim djelatnostima ili nepoljoprivrednim djelatnostima u selu, zapravo predstavlja kočnicu razvoja ruralne sredine.

Tabela 1. Poljoprivredno i nepoljoprivredno, te seosko i gradsko stanovništvo Hrvatske 1953-1991.

Tab. 1: Agricultural and non-agricultural population, rural and urban popu lation in Croatia in the period 1953-1991.

\begin{tabular}{|l|l|l|l|l|l|}
\hline Godina & $\begin{array}{l}\text { Ukupno st. u } \\
\text { tis. }\end{array}$ & $\begin{array}{l}\text { Udio polj. st. } \\
\text { (\%) u } \\
\text { ukupnom st. }\end{array}$ & $\begin{array}{l}\text { Udio nepolj. } \\
\text { st. (\%) u } \\
\text { ukupnom st. }\end{array}$ & $\begin{array}{l}\text { Udio gradskog } \\
\text { st. (\%) u } \\
\text { ukupnom st. }\end{array}$ & $\begin{array}{l}\text { Udio seoskog } \\
\text { st. (\%) u } \\
\text { ukupnom st. }\end{array}$ \\
\hline 1953 & 3936 & 56.4 & 43.6 & 24.2 & 75.8 \\
\hline 1961. & 4160 & 43.9 & 56.1 & 30.8 & 69.2 \\
\hline 1971. & 4426 & 27.4 & 72.6 & 41.1 & 58.9 \\
\hline 1981. & $4391^{*}$ & 15.2 & 84.8 & 48.4 & 51.6 \\
\hline 1991. & $4499^{*}$ & 9.1 & 90.9 & 54.3 & 45.7 \\
\hline
\end{tabular}

* u zemlji I

Izvor/Source: Kušen - Zimberk - Štambuk (1995) 
Čak 77 \% ruralnih područja Hrvatske ima danas karakteristiku izrazitog nazadovanja u razvitku, što označava izrazitu negativnost svih demografskih, socio-kulturnih i prostorno-planskih pokazatelja ${ }^{2}$. Često prometno izolirana, s velikom starošću stanovništva i pretežitim udjelom staračkog i ženskog stanovništva, ta su područja duboko u procesu izumiranja. Samo 11 \% ruralnih područja nalazi se u stagnaciji - prosječnom tipu razvoja koji karakterizira niz povoljnih pretpostavki za brže, lakše i racionalnije usmjeravanje procesa i odnosa. Ipak, konkretnim se mjerama mora djelovati na daljnji razvitak ovih područja jer bez intervencija ona teže zaostajanju u razvoju. 8 \% ruralnih područja nalazi se u okvirima uravnoteženog razvoja, a 4 \% bilježi ekspanziju. Upravo tih 12 \% ruralnih područja trebala bi biti poticajna žarišta u oživljavanju ruralnog prostora, a to je nezaobilazan zadatak jer je "potpuno razoren nekadašnji prostorni, ekonomski, socio-kulturni i ekološki sklad između ruralnog stanovništva i prirodnog okoliša". Ruralni prostor zahvaćen je ekonomskim osiromašenjem, nedostatnom komunalnom i društvenom infrastrukturom. Usitnjeni i neracionalno rasparcelirani posjedi (poljodjelsko zemljište i šume) nerentabilni su i ne pružaju mogućnost za razvoj komercijalne poljoprivrede. I oni posjedi koji su orijentirani prema kvantiteti i imaju potrebne preduvjete suočavaju se $\mathbf{s}$ velikom konkurencijom na tržištu. Razvoj i ulazak novih, nepoljoprivrednih djelatnosti u ruralni prostor često nije planiran proces, već posljedica nemogućnosti egzistencije od bavljenja djelatnostima primarnog sektora. Pao je društveni ugled seljaka. Do ovakve situacije doveo je čitav niz faktora koji su obilježili razvoj sela i ruralnog prostora Hrvatske u prošlosti, prvenstveno od sredine 19.st. i ukidanja kmetstva, do danas.

Revitalizacija sela u smislu održivog i cjelovitog razvoja neophodan je proces očuvanja ruralnih prostora kao primarnih proizvodnih područja hrane i ostalih dobara, područja specifičnog antropogenog pejsaža s naglašenim prirodnim, tradicijskim, kulturnim i historijskim elementima, oaze zelenila i ekološke ravnoteže, i na kraju - kao područja mira i odmora od dinamičnog i stresnog gradskog miljea. Turizam u ruralnom prostoru jedan je od čimbenika koji može imati bitnu ulogu u obnovi i održivom razvitku sela.

2 Rezultati istraživanja provedenog za potrebe "Strategije prostornog uređenja Republike Hrvatske". Navodi u ovom odlomku temelje se na tom izvoru. 


\section{Turizam i rekreacija u ruralnom prostoru}

S razvojem postindustrijskog društva osnovnim funkcijama opstojanja ljudske zajednice pridružuje se i korištenje slobodnog vremena - nova temeljna funkcija tercijarnog društva. Ipak ona nije sasvim nova, već je prerasla iz funkcije odmarati se koja je u agrarnom i industrijskom stadiju razvoja društva označavala prekide rada kao činitelje radne sposobnosti. No njeno je značenje danas posve drugačije. U urbanom (post)industrijskom društvu funkcije raditi i ponašati se u slobodno vrijeme po svojoj su važnosti gotovo izjednačene (Crkvenčić, 1991). Već smo spomenuli da ruralni krajevi ne predstavljaju više samo poljoprivredno-proizvodna područja. Naprotiv, "općenito se može reći da udjel poljoprivredne i šumarske proizvodnje u odnosu na druge funkcije agrarnog područja odgovara stupnju društveno-ekonomskog razvoja kraja. Što je neki kraj društveno-ekonomski razvijeniji (u smislu razvoja od agrarnog preko industrijskog u tercijarno društvo), to je značenje poljoprivredne i šumarske proizvodnje u njegovom ukupnom gospodarstvu u pravilu manje, i obratno." (Crkvenčić, 1991). Ruralni krajevi u suvremenom razdoblju nositelji su slijedećih funkcija: stambena funkcija koja mijenjanjem socioekonomske strukture stanovništva postaje sve složenija, poljoprivredno-proizvodna funkcija, funkcija industrijske proizvodnje, funkcija infrastrukture u službi okolnih urbanih krajeva, te funkcija korištenja slobodnog vremena. Ruralni turizam oslanja se prvenstveno na ovu posljednju funkciju.

Koncept ruralnog turizma razvijao se i mijenjao od svojih početaka do danas. Od 1950-ih kada je bio još samo jedan oblik turizma, i to infrastrukturno slabo razvijen, do danas kada se, zbog svoje uloge u revitalizaciji i transformaciji ruralnih područja izdvaja kao poseban dio turizma i predstavlja ne samo ekonomsku djelatnost, već i element integralnog razvitka ruralnih područja i rurističkog planiranja. Zbog svog karaktera i valorizacije prirodnih obilježja prostora kao ekonomskih resursa, ruralni turizam predstavlja i važnu kariku u lancu održivog razvoja.

Ruralni turizam moguće je tumačiti kao kombinaciju interesa turizma kao ekonomske djelatnosti, okoliša kao kategorije prirodno-ekoloških elemenata i lokalne zajednice kao socijalne strukture sa svim njenim obilježjima. Implementacija tako definirane strukture ruralnog turizma mora slijediti određene principe, npr. racionalno korištenje resursa, "mekani" i postupni pristup, planirani i kontrolirani razvoj, održivost sustava, integraciju znanos- 
ti i tehnologije, uvažavanje modernih marketinških trendova, edukaciju članova lokalnih zajednica...

Ruralni turizam često je bio korišten kao jedan, a ponekad i jedini način za zaustavljanje negativnih i degradacijskih procesa koji su zahvatili ruralna područja u Europi. Spomenuti principi implementacije ruralnog turizma dostignuće su novijeg datuma i nisu uvijek i u potpunosti bili korišteni u razvoju ruralnog turizma. Dok danas razmatramo kombinaciju interesa koji oblikuju ruralni turizam, njegovi postojeći oblici često su bili opterećeni sukobom interesa. To se prvenstveno odnosi na interese lokalnih zajednica i njihovu ulogu u oblikovanju ruralnog turizma. Ruralni turizam imao je veliki utjecaj na socioekonomsku strukturu stanovništva, ali i na njihov način života, tradiciju, ljestvicu moralnih vrijednosti i na mentalitet.

Riječju, rekreacija i turizam u ruralnim prostorima, slijedeći iznesena načela, mogu pridonijeti smanjenju razlike u kvaliteti života između urbanih i ruralnih prostora. Ta je razlika jedan od temelja paradigme o neovisnosti i samodostatnosti gradskog i "ostalog" prostora što pak vodi neuravnoteženom i nekontroliranom razvoju.

\section{Razvoj turizma na seljačkim gospodarstvima u Hrvatskoj}

Hrvatska je danas i turistička zemlja, pretežito okrenuta maritimnom turizmu. lako počeci turizma na hrvatskoj obali sežu u zadnja desetljeća 19. stoljeća, takva se orijentacija izrazito pojavila pedesetih godina 20. stoljeća, a do 70-ih se godina u sklopu litoralizacije gotovo svi turistički interesi premještaju na jadransku obalu. Naš turizam u tom razdoblju pokazuje značajke "maritimne isključivosti" (Kušen, 1995). No u razdoblju do pedesetih naša je turistička ponuda bila diverzificirana. Ruralni prostori često su bili odredištem turista, rekreativaca i gostiju namjernika. Planinarstvo, kulturni i hodočasnički turizam, posjeti zavičaju (najčešće selu) privlačili su mnoge. Turizam nije bio usmjeren na strane goste, ali je egzistirao. Specifičan je i razvoj turizma na seljačkim gospodarstvima. Taj se oblik ruralnog turizma vrlo rijetko pojavljivao u našoj turističkoj ponudi. Sve do 1990-ih on nije bio planiran, štoviše u socijalističkom sustavu bio je dekužiran zbog negativnog stava prema privatnoj svojini, obiteljskim gospodarstvima, te ne-industrijskoj poljoprivredi općenito. Usitnjeni i disperzni seljački posjedi, okrenutost maritimnom turizmu i masovnosti, nedovoljno razvijena svijest o vrijednosti okoliša, samo su neki od faktora koji su utjecali na slab razvoj ovog obli- 
ka ruralnog turizma. Ipak ima i iznimaka. Seljačka su gospodarstva u blizini turistički atraktivnih lokaliteta pružala usluge prenočišta. Litoralizacija jadranske obale donijela je i razvoj turizma na otocima, gdje je uz dubrovačko primorje, Konavle i dijelove Slavonije, postojao turizam na seljačkim gospodarstvima. No njihova je zajednička karakteristika da nisu počivali na nacionalnim programima razvitka sela i ruralnog prostora, već isključivo na domišljatosti i privatnoj inicijativi pojedinaca i grupa. I njihov ukupni broj s obzirom na potencijale ruralnog prostora Hrvatske bio je zanemariv.

Promjenom političkog, društvenog i ekonomskog sustava u Hrvatskoj u devedesetima započinje i nova faza u razvoju ruralnog turizma i posebno turizama na seljačkim gospodarstvima. Upravo je taj oblik jedan od temeljnih nositelja turizma kao čimbenika integralnog razvitka ruralnih prostora, a i taj je aspekt doživio najznačajniju transformaciju. Pored navedenog upravo taj oblik turizma izrazito djeluje na socio-ekonomsku i fiziognomsku preobrazbu seoskih naselja.

Jedan od prvih impulsa koji su potaknuli promišljanje ruralnog turizma u funkciji cjelovitog razvoja sela dao je Savez seljaka Hrvatske osnovan 1990. U svom je Programu Savez istaknuo "seoski turizam" kao važan element razvoja brojnih aspekata ruralne sredine. lako tada nije postojala administrativno-pravna regulativa koja bi podržala ovakvu inicijativu, važnost tog prvog poticaja je u činjenici da je došao od samih seljaka, a već je istaknuto da je lokalna zajednica nezaobilazan element u razvoju ruralnog turizma. No težnje i želje seljaka za razvojem ruralnog turizma grubo su se suočile s činjenicom da znanstvena istraživanja $i$ analize dotad provođene nisu proučavale potencijale razvoja turizma u ruralnim krajevima. Pionirsku ulogu u razvoju stručnih programa za istraživanje mogućnosti razvoja ruralnog turizma u Hrvatskoj tada preuzima Institut za turizam, Zagreb. Zbog nedostatnih financijskih sredstava ovaj projekt nije obuhvatio sve potrebne elemente, ali je pridonio stvaranju osnova za zakonske akte koji će omogućiti razvoj turizma u ruralnim područjima. U planiranje i razvoj uključuje se i konzultantska tvrtka Hrvatski farmer d.o.o. Pune je četiri godine turizam na seljačkim gospodarstvima bio izvan zakonskih okvira, ali je i stvoren prijedlog klasifikacije ruralnog turizma u Hrvatskoj, temeljen uglavnom na iskustvima europskih zemalja. Autor prijedloga E. Kušen smatra da ruralni turizam objedinjuje 19 mogućih vrsta turizma: turizam na seljačkom gospodarstvu, rezidencijalni turizam, zavičajni turizam, športskorekreacijski turizam, avanturistički turizam, zdravstveni turizam, edukacijski turizam, tranzitni turizam, kamping turizam, nautički kontinentalni turizam, 
kulturni turizam, vjerski turizam, lovni turizam, ribolovni turizam, vinski turizam, gastronomski turizam, prirodi bliski turizam, eko-turizam, mješovite i ostale vrste turizma.

Pojmu seljački umjesto seoski u nazivu turizam na seljačkim gospodarstvima, dana je prednost, iako mnogi naglašavaju pejorativni prizvuk te riječi, jer se i u većini država Europe taj pridjev izvodi iz naziva seljak (kmet, Bauer) ili pojma seljačko gospodarstvo (farm, ferm, Bauernhof, kmetija), ali nigdje iz naziva selo (village, Dorf, vas).

Turizam na seljačkom gospodarstvu oblik je turizma na koji se najčešće pomisli pri razmišljanju o ruralnom turizmu. Turističko seljačko gospodarstvo je manja gospodarska cjelina, smještena u turistički atraktivnom kraju, koja daje izvoran proizvod ili uslugu gospodarstva, a u rad su uključeni svi članovi obitelji. Poljoprivredno, obiteljsko, seljačko gospodarstvo koje pruža turistički proizvod ili uslugu stječe status "turističkog obiteljskog gospodarstva". Turizam na obiteljskom gospodarstvu samo je dopunska djelatnost. Upravo ovaj element definicije određuje smisao ove vrste turizma. Turizam na seljačkom gospodarstvu pruža dodatni, dopunski izvor prihoda gospodarstvu koje primarni izvor prihoda stječe iz poljoprivredne djelatnosti. Time se osigurava preživljavanje rurisa i kao primarnog proizvođača hrane - njegove izvorne funkcije. Štoviše, usluga prehrane, jela i pića za goste na turističkom seljačkom gospodarstvu trebala bi biti sastavljena iz namirnica pretežito vlastite proizvodnje. Članovi domaćinstava koje pruža turističku uslugu moraju imati prebivalište na selu.

Ovakvu klasifikaciju slijedio je i Zakon o ugostiteljskoj djelatnosti donešen 1995. Iduće je godine donesen i Zakon o turističkoj djelatnosti, a na temelju njega i Pravilnik o pružanju ugostiteljskih usluga na seljačkom domaćinstvu (1996.). Narednih su godina uslijedile dopune i izmjene postojećeg Pravilnika i Zakona, i iako postoje nedostaci, ovi akti predstavljaju polazište za cjeloviti razvoj turizma u ruralnim područjima.

Tijekom razvoja koncepta ruralnog turizma u Hrvatskoj, od vladinih institucija koje su podržale aktivnosti na ovom planu možemo istaknuti Ministarstvo turizma koje je 1994. osnovalo "Savjet za ruralni razvitak". Svjesno važnosti koju turizam može imati u hrvatskom gospodarstvu, ali i činjenice da se "turističko tržište mijenja i da je ono danas izuzetno ekološki svjesno, zainteresirano doživjeti tipičnu atmosferu i posebnost mjesta koja se posjećuju, te cijeni bogatstvo rekreacijskih, zabavnih i sportskih 
sadržaja" (Cetinski, Katica, 1998.) kao i da se borba za povratak na međunarodnu turističku scenu ne može dobiti isključivo "sun and beach" turizmom, Ministarstvo je razvilo program "Razvitak turizma u ruralnom prostoru". Cilj je ovog programa obnova, valorizacija i zaštita hrvatskih turističkih potencijala te stvaranje integralnog turističkog proizvoda, ali kao sastavnice ukupnog, održivog razvitka ruralnih područja. Ističe se također da je ovaj program sukladan pripremnim aktivnostima Hrvatske za ulazak u Europsku Uniju i PHARE program. Doprinos Programa se očekuje u sferi gospodarstva, zaposlenosti, razvoja županija, razvoja otoka, demografske obnove i realizacije socijalnog programa. Konkretne aktivnosti u 1999. odnosile su se na poticanje 400 malih poduzetnika u turizmu na ruralnom području uključujući i otoke, s ukupno 2400 uvjetnih smještajnih jedinica.

\section{Analiza postojećeg stanja}

S ožujkom 2000. u Hrvatskoj je bilo 117 registriranih turističkih seljačkih obiteljskih gospodarstava u 13 županija. Većinu od njih predstavljaju izletnička gospodarstva, bez mogućnosti smještaja. No mješoviti oblici, s obrtom ili sl. nude nešto veću ponudu. 1998. bilo je 32, a 1999. 74 registrirana gospodarstva, što znači da je njihov broj u dvije godine povećan za više od tri puta. No postoje i oni, pogotovo u primorskim mjestima, koji su svoju ponudu registrirali kao uslugu privatnog smještaja, iako su u biti bliski turističkom seljačkom gospodarstvu.

Već i površna analiza otkriva velike regionalne nejednakosti. Prednjači Istra s $38.5 \%$ od ukupno registriranih turističkih seljačkih gospodarstava. Slijedi Dubrovačko-neretvanska županija s $19.7 \%$. Ističu se još Zadarska (12 \%) i Zagrebačka (6.8 \%). Valja napomenuti da su gospodarstva u Zadarskoj županiji, iako čine 12 \% od ukupnog broja, tijekom 2000. tek započinjala s pripremom za ovu vrstu turizma i mnoga od njih nisu primala goste.

Osim broja turističkih seljačkih gospodarstava važan je i ostvareni broj noćenja. Turistička noćenja izuzetno su važan element osiguravanja prihoda od bavljenja ovom djelatnošću jer omogućavaju duži boravak gostiju na jednom obiteljskom gospodarstvu, a najčešće su povezana i s uslugom ponude hrane na samom gospodarstvu. Time se ne povećavaju samo prihodi gospodarstva, već se znatno podiže kvaliteta ponude i doživljaj boravka. 
Slika 1: Broj i prostorni razmještaj registriranih turističkih seljačkih gospo darstava u Hrvatskoj 2000.

Map 1: Number and location of registered tourism on farms units in Croatia in 2000.

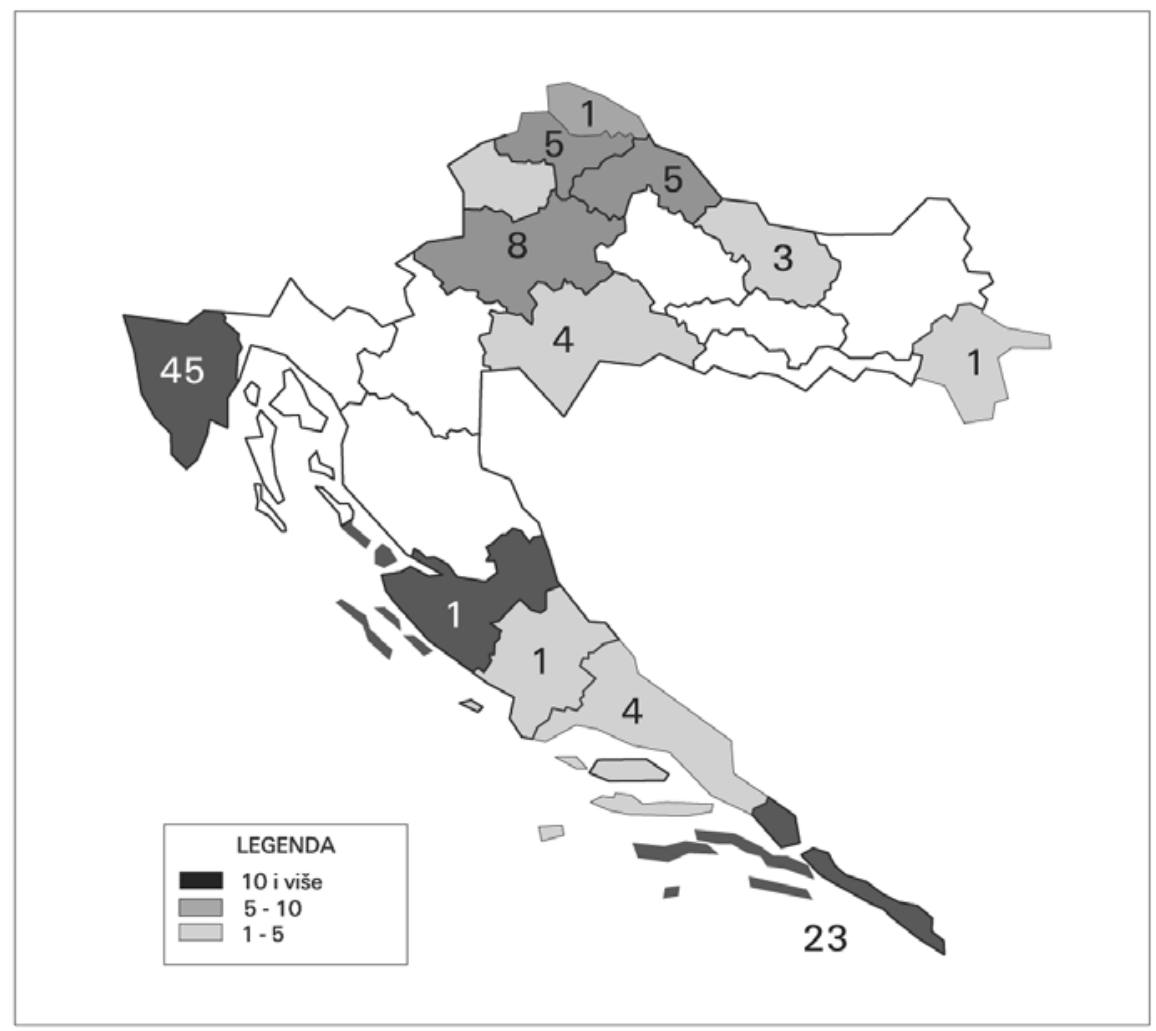

Vir/Source:

Na turističkim seljačkim obiteljskim gospodarstvima u Hrvatskoj (obrađena su 102 od 117 gospodarstava ili 87.2 \%) u 2000. ostvareno je približno 12 863 noćenja (tab. 3). Taj broj jednak je udjelu od $0.03 \%$ u ukupnom broju noćenja ostvarenih u Hrvatskoj tijekom 2000.g. Najveći udio broja noćenja na turističkim seljačkim gospodarstvima u ukupno ostvarenim noćenjima ima Dubrovačko-neretvanska županija (1 \%), a najmanji Zagrebačka županija (i grad Zagreb) od $0.003 \%$. 
Tabela 2: Promjena broja registriranih turističkih obiteljskih seljačkih gospo darstava u Hrvatskoj 1998. - 2000.

Tab. 2: Number of registered tourism on farms units in Croatia in the peri od 1998-2000.

\begin{tabular}{|l|l|l|l|l|}
\hline Županije & $\begin{array}{l}\text { Potencijalna } \\
1998 .\end{array}$ & 1998. & 1999. & 2000. \\
\hline I Zagrebačka & 0 & 8 & 10 & 8 \\
\hline II Krapinsko-zagorska & 0 & 2 & 3 & 3 \\
\hline III Sisacko-moslavačka & 31 & 0 & 3 & 4 \\
\hline V Varazdinska & 2 & 3 & 5 & 5 \\
\hline VI Koprivnicko-križevačka & 0 & 0 & 0 & 5 \\
\hline VII Bjelovarsko-bilogorska & 1 & 0 & 0 & 0 \\
\hline X Virovitičko-podravska & 9 & 0 & 6 & 3 \\
\hline XIII Zadarska & 0 & 0 & 0 & 14 \\
\hline XV Šibensko-kninska & 5 & 0 & 1 & 1 \\
\hline XVI Vukovarsko-srijemska & 0 & 1 & 0 & 1 \\
\hline XVII Splitsko-dalmatinska & 2 & 6 & 12 & 4 \\
\hline XVIII Istarska županija & 0 & 10 & 27 & 45 \\
\hline XIX Dubrovačko-neretvanska & 0 & 0 & 5 & 23 \\
\hline XX Medimurska županija & 0 & 2 & 2 & 1 \\
\hline UKUPNO & 50 & 32 & 74 & 117 \\
\hline
\end{tabular}

Izvor/Source: HGK, 1998-2000.

Iz podataka o broju gospodarstava i broju ostvarenih noćenja na turističkim seljačkim obiteljskim gospodarstvima, te prostornom rasporedu takve vrste turizma u Hrvatskoj, moguće je izvesti nekoliko zaključaka.

Jasno se nameće činjenica da je udio turizma na seljačkim gospodarstvima, uzimajući u obzir broj ostvarenih noćenja, zanemariv u ukupnom turizmu Hrvatske. Ali ta činjenica nije dovoljno relevantan pokazatelj postojeće situacije. Primjer Austrije, države koja je poznata po efikasnom korištenju ruralnog turizma u funkciji razvitka prostora, jasno pokazuje da "gledajući cjelokupan turizam u Austriji, izražen brojem noćenja i udjelom u brutto domaćem proizvodu, turizam na seljačkim gospodarstvima ima samo malu ulogu. Ali trenutno ta ekonomska aktivnost pridonosi održivosti $10 \%$ svih farmi u državi. Prema "Zelenom izvještaju" (1991) prihod od turizma na farmama u podnožju Alpa iznosi $11.5 \%$, a onih u najvišim dijelovima Alpa 31.6 \% od ukupnih prihoda. Upravo činjenica da u Hrvatskoj postoji samo 117 
Tabela 3: Usporedni pregled broja turističkih seljačkih gospodarstava i ost varenih noćenja, te ukupnog broja noćenja u Hrvatskoj 2000.

Tab. 3: Overview on the number of tourism on farms units and overnight stayings in Croatia in 2000.

\begin{tabular}{|l|l|l|l|l|}
\hline & Zroj turističkih & $\begin{array}{l}\text { Priblizan broj } \\
\text { noćenja } \\
\text { na obrađenim } \\
\text { turističkim } \\
\text { seljackih } \\
\text { obiteljskih } \\
\text { gospodarsim } \\
\text { (tsog) } \\
\text { obiteljskim } \\
\text { gospodarstvima } \\
\text { (102/117) }\end{array}$ & $\begin{array}{l}\text { Ukupn broj } \\
\text { nočenja u } \\
\text { županiji }\end{array}$ & $\begin{array}{l}\text { Udio broja } \\
\text { noćenja na } \\
\text { tsog u } \\
\text { ukupnom } \\
\text { broju } \\
\text { noćenja } \\
\text { (\%) }\end{array}$ \\
\hline $\begin{array}{l}\text { I Zagrebačka županija i grad } \\
\text { Zagreb }\end{array}$ & 8 & 15 & 572671 & 0.003 \\
\hline II Krapinsko-zagorska & 3 & 343 & 80455 & 0.4 \\
\hline III Sisacko-moslavačka & 4 & 20 & 32617 & 0.06 \\
\hline V Varazdinska & 5 & - & 113052 & \\
\hline VI Koprivničko-križevačka & 5 & 1075 & 37701 & 2.9 \\
\hline X Virovitičko-podravska & 3 & 90 & 1942 & \\
\hline XIII Zadarska & 14 & 2132 & 3349010 & 0.06 \\
\hline XV Šibensko-kninska & 1 & - & 1904970 & \\
\hline XVI Vukovarsko-srijemska & 1 & 0 & 39586 & 0 \\
\hline XVII Splitsko- dalmatinska & 4 & 607 & 5637184 & 0.01 \\
\hline XVIII Istarska & 45 & 5550 & 14719419 & 0.04 \\
\hline XIX Dubrovačko-neretvanska & 23 & 3031 & 2778585 & 1 \\
\hline XX Medimurska & 1 & 0 & - & 0 \\
\hline Ostale & 0 & 0 & 10166170 & 0 \\
\hline UKUPNO & 117 & 12863 & 39433362 & 0.03 \\
\hline & & & & \\
\hline
\end{tabular}

Izvor/Source: HGK, HTZ, županijske turističme zajednice, registrirana seljačka gospodarstva.

registriranih seljačkih gospodarstava koja razvijaju turizam i time pridonose održivosti ukupnog ruralnog prostora (kojega su obiteljska gospodarstva temelj u suvremenom svijetu) poražavajuća je istina.

Poteškoće u prikupljanju podataka zbog činjenice da se broj dolazaka i noćenja na turističkim seljačkim obiteljskim gospodarstvima još uvijek ne evidentira zasebno u županijskim turističkim zajednicama i ne uvodi u službene statističke publikacije, činjenica da postoje znatna zaobilaženja postojećeg zakonskog okvira registracije, vrijeme donošenja i primjedbe na 
postojeće zakonske akte koji reguliraju ovu problematiku, nedovoljno dostupan i nepovoljan sustav kreditiranja poduzetničkih podhvata, neprepoznatljivost ruralnog turizma u hrvatskom turističkom proizvodu, a jasno i vrlo mali broj gospodarstava koja se bave turizmom u ruralnim prostorima, mogu potkrijepiti jednu od hipoteza postavljenih na početku rada: turizam na seljačkim obiteljskim gospodarstvima u Hrvatskoj nalazi se u pionirskoj, početnoj fazi razvoja.

Promatrajući prostorni raspored registriranih turističkih seljačkih gospodarstava u odnosu na socijalno-ekonomsko stanje pojedinih dijelova ruralne Hrvatske, neizbježan je zaključak da prostori s najizraženijim obilježjima sveopće krize najmanje sudjeluju u turizmu na seljačkim obiteljskim gospodarstvima, koji je kako je već istaknuto, dokazano sredstvo revitalizacije i integralnog razvitka nekih ruralnih područja Europe. Nepostojanje ovakve ponude ruralnog turizma u npr. Ličko-senjskoj, Primorsko-goranskoj, Karlovačkoj ili Bjelovarsko-bilogorskoj županiji, te samo četiri registrirana obiteljska seljačka gospodarstva u Sisačkomoslavačkoj županiji, potvrđuju navedeni zaključak.

Turizam na seljačkim gospodarstvima u Hrvatskoj najrazvijeniji je u primorskom prostoru, točnije u Istarskoj županiji. U županijama s izlazom na Jadransko more nalazi se 87 od ukupno 117 registriranih obiteljskih seljačkih gospodarstava (74.4 \%) i u njima je tijekom 2000. ostvareno 11320 noćenja ( $88 \%$ od ukupnog broja noćenja). lako brojna iskustva iz svijeta pokazuju da spoj sun \& beach i ruralnog turizma nisu nužna za njegov razvoj jer gosti koji odabiru turistička seljačka gospodarstva imaju drugačije poimanje odmora, evidentno je, iz primjera Istarske i Dubrovačkoneretvanske županije, da raznolikiji privlačni faktori, uz razvijeniju turističku infrastrukturu i tradiciju bavljenja turizmom, imaju važnu ulogu.

\section{Zaključak}

Ruralni prostor Hrvatske je u kolopletu zbivanja u prošla dva stoljeća gospodarski, socijalno i prostorno izimjenjen. Većina procesa ekonomske i političke naravi rezultirala je negativnim obilježjima rurisa na kraju 20.stoljeća. 3/4 ruralnog prostora Hrvatske obilježeno je izrazitim zaostajanjem u razvoju - sintetičkim pokazateljem demografske i ekonomske stvarnosti. Procesi globalizacije i tercijarizacije ulaze i u Hrvatsku. Sukob tradicijskog i modernog, starog i novog poprima novu dimenziju. Ruralni krajevi Hrvatske dostižu kritičnu točku pražnjenja. 
Slika 2: Noćenja na registriranim turističkim seljačkim gospodarstvima 2000.

Map 2: Over-night stays on registered tourism on farms units in 2000.

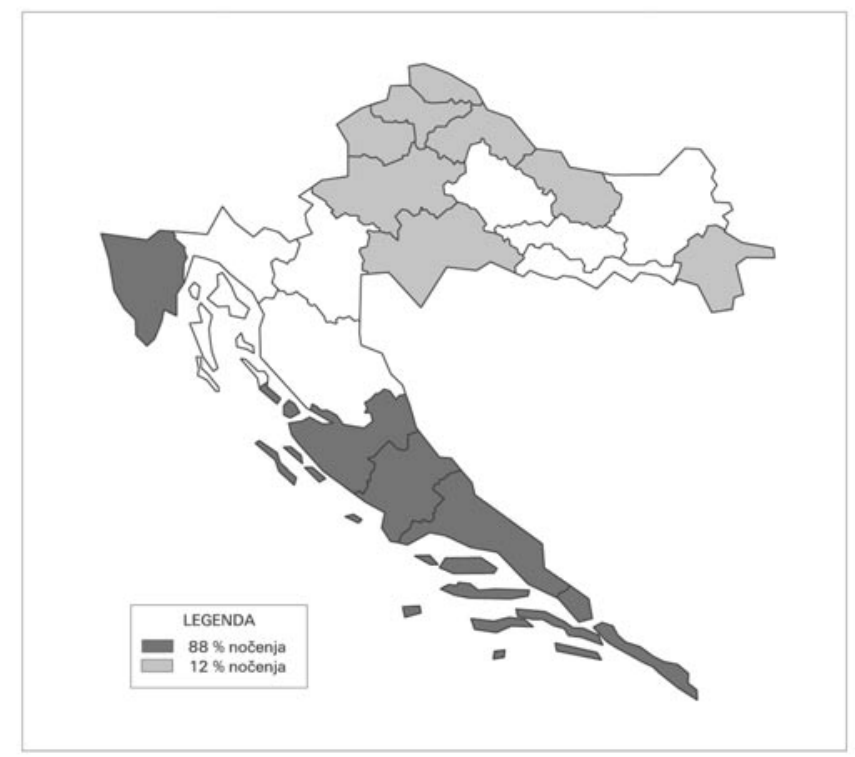

Usprkos prepoznavanju važnosti ruralnog turizma kao mogućeg sredstva u razvoju ruralnih prostora, Hrvatska se nalazi u pionirskoj, početnoj fazi razvoja ovog oblika turizma, a posebno turizma na seljačkim obiteljskim gospodarstvima. Zakonski okvir donešen je 1995. Tijekom 2000. bilo je registrirano samo 117 takvih gospodarstava koja su ostvarila tek $0.03 \%$ od ukupnog broja noćenja u Hrvatskoj. Čak 3/4 od ukupnog broja gospodarstava nalazi se u županijama s izlazom na more i tamo je ostvareno oko $90 \%$ od ukupnog broja noćenja na turističkim seljačkim gospodarstvima u Hrvatskoj (prednjači Istra). Turizam na seljačkim gospodarstvima ne koristi se kao sredstvo revitalizacije i integralnog razvoja ruralnih područja. Županije s izrazito negativnim socijalno-ekonomskim obilježjima ruralnog prostora (Ličko-senjska, Primorsko-goranska, Sisačko-moslavačka, Karlovačka, ...) gotovo i nemaju turističkih seljačkih obiteljskih gospodarstava. Razvoj turizma na seljačkim gospodarstvima opterećen je neprepoznatljivošću u turističkom proizvodu Hrvatske, netransparentnom sustavu organizacije subjekata vezanih uz takav oblik turizma, te nepovoljnom mogućnošću financiranja poduzetničkih projekata. 
Hrvatska ima osnove za razvoj ruralnog turizma i turizma na seljačkim gospodarstvima. Procjenjuje se da je moguće razviti 15000 turističkih seljačkih gospodarstava s ukupno 150000 kreveta i 100000 u kreveta ostalim smještajnim kapacitetima u ruralnom prostoru ${ }^{3}$. Sustavan razvoj ove vrste turizma u problemskim ruralnim prostorima pridonio bi njihovoj revitalizaciji.

\section{TOURISM ON FARMS IN CROATIA}

\section{Summary}

Important economic, social and spatial changes took place in the Croation rural area in the last two centuries. A geart part of economic and political processes had caused negative characteristics of rurality at the end of the last century. $75 \%$ of Croation rural space has less favourable features in demographic and economic field. The globalisation and the development of terciary sector of activity take place in Croatia. Tradition and contemporary demands on standard of living are faced intensively. The rural areas have reached a critical poinz of emigration of the population.

In spite of the conciousness of the importance of tourism on farms as the way of development the Croation rural space enter in the initially phase of its development. The first law regulating the tourism on farms have been implemented as far as in the year 1995. In 2000, there was only 117 farms being engaged in tourism activities, $75 \%$ of them are located in the vicinity of the Adriatic coast, most of them on Istra peninsula. The tourism on farms is not used as the manner of revitalisation and integral development of rural areas. Lack of organisation of tourism on farms by the state institutions, lack of funds and investments are the main problems of modernisation of rural space through the tourism on farms.

Possibilities for development of the tourism on farms are evident. The investigations give opportunity to 15000 farms to be engaged at the tourism with 150000 beds on the proper farms and 100000 beds at the other holders in the rural areas.

\footnotetext{
3 Procjena dr. E. Kušena.
} 


\section{Viri i literatura}

Cetinski, V., Katica, D., 1998: Turizam i održivi razvitak hrvatskog ruralnog područja, Zbornik radova - Turizam i održivi razvitak hrvatskog ruralnog prostora, Turistička zajednica grada Varaždina, 1-9.

Cetinski, V., 1996: Bitne odrednice turističke politike, Zbornik radova - Turizam na seljačkim gospodarstvima - mogućnosti i ograničenja, Hrvatski farmer d.d., 1-4.

Crkvenčić, I., Malić A. , 1988: Agrarna geografija, Školska knjiga, Zagreb.

Crkvenčić, I. , 1991: Turizam u agrarnim područjima, Acta turistica, vol 3, 8-28.

ECOVAST, 1994: A Strategy for Rural Europe, European Council for Villages and Small Towns.

Hrvatska gospodarska komora, 1999: Turizam na seljačkim gospodarstvima, Zagreb.

Hrvatska gospodarska komora, 2000: Registrirana turistička seljačka obiteljska gospodarstva (interna publikacija), Zagreb.

Katica, D., Soldo, Z., 1997: Postojeće stanje, Zbornik radova - Ruralni turizam - jedan od čimbenika obnove sela i cjelovitog razvitka ruralnog prostora, Hrvatski farmer d.d., Zagreb, 40-47.

Koščak, M., 1995: Razvoj ruralnog turizma u Sloveniji, Turizam 7-8, Hrvatska turistička zajednica i Institut za turizam, 134-142.

Kušen, E., 1995: Turizam na seljačkom gospodarstvu, Turizam 7-8, Hrvatska turistička zajednica i Institut za turizam, 127-133.

Kušen, E., Štambuk, M., Žimbrek, T. ,1995: Uređenje, razvoj i obnova ruralnog prostora.

Kušen, E. , 1997: Strateški okvir razvitka ruralnog turizma kao dio koncepta cjelokupnog razvitka ruralnog prostora i obnove sela, Zbornik radova - Ruralni turizam - jedan od čimbenika obnove sela i cjelovitog razvitka ruralnog prostora, Hrvatski farmer d.d., Zagreb, 48-51.

Middleton, V.T.C., 1982: Tourism in rural areas, Tourism Management 3:1, 52-58.

Ministarstvo prostornog uredenja, graditeljstva i stanovanja (1997): Strategija prostornog uređenja Republike Hrvatske, Naklada Zadro.

Nejašmić, I. , 1991: Depopulacija u Hrvatskoj, Globus i Institut za migracije i narodnosti u Zagrebu.

Puljić, A., 1996: Problemi ruralnih područja u Hrvatskoj i potreba njihove brže obnove i razvitka, Sociologija sela 34 (3/4), Institut za društvena istraživanja u Zagrebu. 